\title{
Effect of 1.2-epoxy-3[3-3[3.4-dimetoxyi- phenil]-4h-1-benzopiran-4-on] Propane (epi) on Sirtuin-1 and Nuclear Factor- $\kappa B$ Expression of DMBA induced Mammary Tumors in sprague dawley rats
}

\author{
Ayyub Harly Nurung ${ }^{1}$, Sri Herwiyanti ${ }^{1}$, Dewi Kartikawati Paramita ${ }^{1}$ \\ ${ }^{1}$ Department of Histology and Cell Biology, Faculty of Medicine Universitas Gadjah Mada
}

DOI: http://dx.doi.org/10.19106/JMedSci004803201602

\begin{abstract}
The main factors contribute to breast cancer development is the combination of exogenous

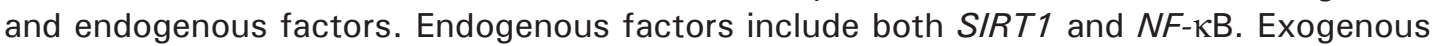
factor used in this research is 7.12 dimethylbenz( $\alpha$ )anthracene (DMBA). 1,2-epoxy-3[33[3,4-dimetoxy-phenil]-4h-1-benzophiran-4-on] propane (EPI) is a derivative of isoflavone generate from clove leaf oil. To examine the effect of EPI on SIRT1 and NF-KB expression in DMBA-induced Sprague Dawley (SD) rats, and the correlation between SIRT1 and NF$\kappa B$ expressions. Tissue generated form 35 Sprague Dawley female rats aged 2 weeks old were used in this study. Those rats were divided into 7 groups ( 5 rats/group), namely normal control group; corn oil group; DMBA group; EPI treated groups with $1 \mathrm{mg} / \mathrm{kgBW}$ (EPI I), $2 \mathrm{mg} / \mathrm{kgBW}$ (EPI II), and $4 \mathrm{mg} / \mathrm{kgBW}$ (EPI III), respectively; and doxorubicin group. EPI and doxorubicin were administered from $1^{\text {st }}$ until $15^{\text {th }}$ week, while DMBA were administered from $3^{\text {rd }}$ until $9^{\text {th }}$ week. The paraffin block was prepared from all breast organ of the rats that terminated at the end of week $15^{\text {th }}$. Examination of SIRT1 and $N F-\kappa B$ expression was performed using light microscope at 400x magnifications, after immunohistochemistry (IHC) staining. Expression level of SIRT1 and NF- $\mathrm{B}$ were analyzed using IHC-profiler plug-in in ImageJ software. SIRT1 and $N F-\kappa B$ expression in EPI treated groups were not significantly different with the one in Doxorubicin group, but lower than DMBA group $(\mathrm{p}=0.000)$. There was a positive correlation between SIRT1 and $N F-\kappa B$ expression $(p=0.001 ; r=0.773)$ in EPI-treated group. EPI was able to prevent an increasing of SIRT1 and $N F-\kappa B$ expression in $S D$ model breast cancer that induced with DMBA. There is a positive correlation between SIRT1 and NF-KB expression in EPI-treated $S D$ rats that were induced by DMBA.
\end{abstract}

\section{ABSTRAK}

Faktor utama penyebab kanker payudara adalah kombinasi faktor endogen dan eksogen. Faktor endogen antara lain adalah ekspresi SIRT1 dan NF-אB dan Faktor eksogen yang digunakan untuk penelitian ini adalah 7.12 dimethylbenz( $\alpha$ )anthracene (DMBA). 1, 2-epoxy3[3-3[3,4-dimetoxy-phenil]-4h-1-benzophiran-4-on] propane (EPI) merupakan turunan isoflavone yang disintesis dari minyak daun cengkeh. Untuk mengkaji pengaruh EPI 
terhadap SIRT1 dan NF-KB pada tikus Sprague Dawley yang diinduksi dengan DMBA dan mengkaji hubungan antara ekspresi SIRT1 dan NF-KB. Penelitian ini menggunakansampel blok paraffin yang dihasilkan dari 35 tikus betina Sprague Dawley yang dibagi dalam 7 kelompok ( 5 tikus/kelompok), yaitu kontrol tanpa perlakuan, kelompok minyak jagung, kelompok DMBA, kelompok perlakuan EPI dosis $1 \mathrm{mg} / \mathrm{kgBB}$ (EPI I), $2 \mathrm{mg} / \mathrm{kgBB}$ (EPI II), dan $4 \mathrm{mg} / \mathrm{kgBB}$ (EPI III), serta kelompok doksorubisin. Parafin blok disiapkan dari semua jaringan payudara tikus. Pemeriksaan ekspresi SIRT1 dan NF-KB dilakukan menggunakan mikroskop cahaya perbesaran $400 X$ setelah pewarnaan imunohostokimia dengan antibody anti SIRT1 dan anti $N F-\kappa B$. Tingkat ekspresi SIRT1 dan $N F-\kappa B$ dinilai menggunakan software Image J. Ekspresi SIRT1 and NF-KB pada kelompok EPI tidak berbeda nyata dengan kelompok Doxorubicin, tetapi lebih rendah daripada kelompok DMBA $(p=0.000)$. Terdapat korelasi positif antara tingkat ekspresi SIRT1 and NF-KB $(\mathrm{p}=0.001 ; \mathrm{r}=0.773)$ pada kelompok perlakuan EPI. EPI dapat mencegah peningkatan ekspresi SIRT1 and NFKB pada model tikus kanker payudara yang diinduksi dengan DMBA. Terdapat korelasi positif antara tingkat ekspresi SIRT1 and NF-KB $(\mathrm{p}=0.001 ; \mathrm{r}=0.773)$ pada tikus model yang diberi EPI.

Keywords: Isoflavone, SIRT1 expression, NF-KB expression, breast cancer, EPI, DMBA, Sprague Dawley rats.

\section{INTRODUCTION}

Breast cancer is the most common cancer in women. In Indonesia, the incidence of breast cancer is $20-30 / 100.000$ per year. ${ }^{1}$ According to the data from Ministry of Health Republic of Indonesia in 2013, breast cancer is the second highest cancer in Indonesia, approximately $0.5 \%$ of total population of Indonesia. The highest prevalence rate is in D.I Yogyakarta Province, approximately 2.4\%. It is estimated that the most of breast cancer patients are in East Java (11.511 patients) and Central Java (9.688 patients). ${ }^{2}$ The biggest contribution to breast cancer pathogenesis is the combination of exogenous and endogenous factors. The exogenous factors included diet, alcohol and pollution, and the endogenous factors included estrogens and progesterone exposures; and others. ${ }^{3}$ In this study we use 7.12 dimethylbenz $(\alpha)$ anthracene (DMBA) for tumor induction as the exogenous factor, while SIRT1 (Silent information regulator 1) and NF- $\mathrm{BB}$ (Nuclear factor-kappaB) are examined as the endogenous factor.
SIRT1 is a NAD+-dependent histone deacetylase, which is involved in multiple biologic processes in several organisms. ${ }^{4}$ SIRT1 does not only deacetylate histone but also some regulator gene such as $\mathrm{p} 53,{ }^{5} \mathrm{p} 73^{6}$ and $\mathrm{Rb}^{7}$ It has been reported that SIRT1 regulates cell proliferation, survival, and death, and plays a pivotal role in tumorigenesis and longevity. ${ }^{8} \mathrm{NF}-\kappa \mathrm{B}$ is a protein that regulate nearly every aspect of tumor biology, including the promotion of cell survival, induction of cell proliferation, the promotion of metastasis and stimulation of angiogenesis. ${ }^{9}$ $\mathrm{NF}-\kappa \mathrm{B}$ plays role in inhibiting apoptosis, but it can enhances proliferation in several breast cancer cells. ${ }^{10}$

1.2-epoxy-3[3-3[3.4-dimetoxy-phenil]4h-1-benzophiran-4-on] propane (EPI) is an isoflavone derivatives, as well as genistein, daidzine, and glisetine. It is a synthetic compound made of clove leaf oil. ${ }^{11}$ In vivo study showed that EPI inhibits the formation and enlargement of nodule, and improve the histological structure of breast tumor tissue of induced tumor in SD rats. Furthermore, 
EPI can inhibit angiogenesis and cell proliferation. ${ }^{12}$ However, the study of the effect of EPI on SIRT1 and NF- $\kappa$ B expression never been reported. Therefore, this study aimed to examine the effect of EPI on SIRT1 and NF- $\kappa \mathrm{B}$ expression in DMBA induced Sprague Dawley rats, and to examine the correlation of SIRT1 and NF- $\kappa$ B expression in DMBA induced Sprague Dawley rats treated with EPI.

\section{METHODS}

\section{Research Sample}

The samples used in this study are tissues generated from paraffin blocks taken from 35 Sprague Dawley rats that divided into 7 groups. The groups are normal group, control-solvent groups (corn oil), DMBA group (solvent + DMBA), EPI 1 groups (1 $\mathrm{mg} / \mathrm{kgBW}$ EPI + DMBA + solvent), EPI II group ( $2 \mathrm{mg} / \mathrm{kgBW} \mathrm{EPI}+\mathrm{DMBA}+$ solvent), EPI III group ( $4 \mathrm{mg} / \mathrm{kgBW}$ EPI + DMBA + solvent), and doxorubicin group ( $8 \mathrm{mg} / \mathrm{kgBW}$ doxorubicin + DMBA + solvent $).{ }^{12}$

\section{Immunohistochemistry (IHC) staining of SIRT1 and NF-KB}

The expression of SIRT 1 and NF- $\mathrm{BB}$ p65 was performed by immunohistochemistry (IHC) staining using kit from BIOCARE (STUHRP700H, L10). The antibodiy used to localized the expression of SIRT1 was from ABCAM (AB110304); and antibody antiNF- $\kappa$ B p65 was from Santa Cruzz Bio (SC8008). The staining was done according to SOP P-013 Laboratory of Histology and Cell Biology, Faculty of Medicine, Universitas Gadjah Mada.

\section{Examination of SIRT1 and NF-кB expression}

SIRT1 and NF- $\kappa B$ were examined using light microscope from 5 different perspectives with 400x magnifications . The calculation of the expression level was performed using IHC-profiler plug-in in ImageJ software. The principles of the software is color deconvolution and analysing the images pixel-by-pixel in order to obtain a score automatically. ${ }^{13}$ The result of Image $J$ is the scores of expression level, which are negative (0), low positive (1), positive (2), and high positive (3), and the data showed in mean.

\section{Statistical analysis}

The difference of SIRT1 and NF- $\mathrm{BB}$ expressions among groups were analyzed using of one-way ANOVA and post-hoc Bonferroni. The correlation between SIRT1 and NF- $\kappa \mathrm{B}$ expressions in EPI-treated groups were analyzed by Spearman test.

\section{Ethical issues}

This research was approved by ethical committee Faculty of Medicine, Universitas Gadjah Mada Yogyakarta (Ethical Clearance Number KE/FK/481/EC).

\section{RESULT}

\section{The effect of EPI in SIRT1 expression among different rat groups.}

SIRT1 expression could not be found in normal group and corn oil group. While, the expression can be observed in DMBA group, EPI group, and Doxorubicin group. The strongest expression of SIRT1 can be observed in DMBA group (Figure 1).

Based on the measurement using Image $\mathrm{J}$, the lowest SIRT1 expression was found in normal group $(0.12 \pm 0.035)$ and the highest expression was found in DMBA group $(0.49 \pm 0.062)$. SIRT1 expression in EPI groups were generally lower than the one in DMBA group, corresponds to $0.27 \pm 0.072$ for EPI I, 
$0.19 \pm 0.038$ for EPI II, and $0.14 \pm 0.025$ for EPI III. The SIRT1 expression in doxorubicin group $(0.14 \pm 0.30)$ is closely similar to EPI III (Table 1).

One-way ANOVA with post hoc Bonferroni test indicated that there is no significant difference between normal group and corn oil group ( $\mathrm{p}=1.000$; data considered significantly different if $p<0.05$ ) (Table 1 ). It was indicated that corn oil as DMBA solvent does not affect SIRT1 expression. One-way ANOVA test showed that SIRT1 expression in DMBA group was significantly different to normal group $(\mathrm{p}=0.000)$. Meanwhile, SIRT1 expression in EPI groups (EPI I, II EPI and EPI III) were significantly lower the one in DMBA group $(p=0.000)$. SIRT1 expression in EPI III significantly lower than EPI I ( $p$ $=0.001)$. Moreover, SIRT1 expression in doxorubicin group was significantly lower compared to DMBA group $(\mathrm{p}=0.000)$ and EPI I $(p=0.002)$, but did not significantly different from EPI II $(p=1.000)$ and EPI III $(p=1.000)$.
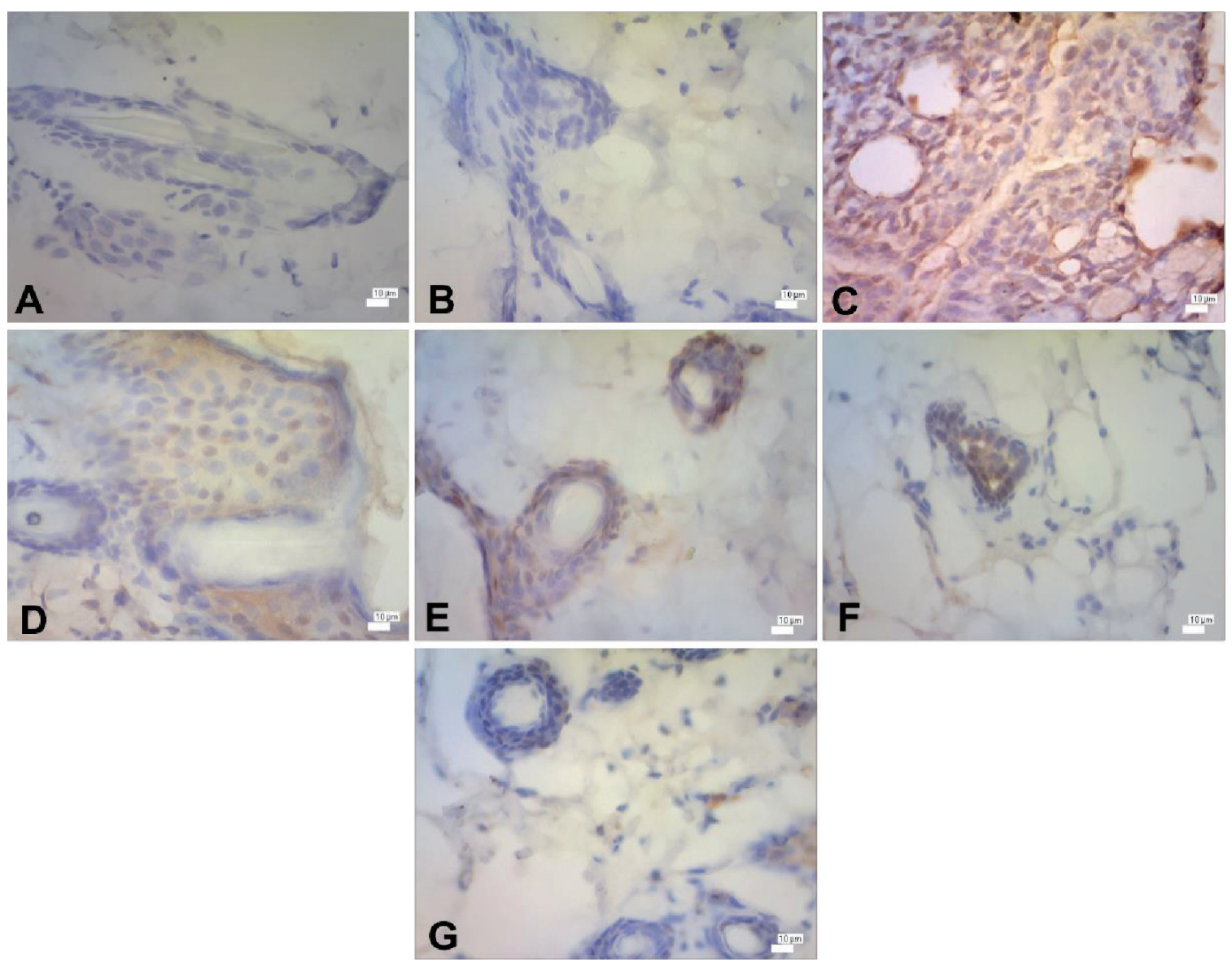

FIGURE 1. SIRT1 expression in (A) Normal group; (B) Corn oil group; (C) DMBA group; (D) EPI I group (1 $\mathrm{mg} / \mathrm{kgBW}$ EPI); (E) EPI II group (2 mg/kgBW EPI); (F) EPI III group (4 mg/kgBW EPI); and (G) Doxorubicin group ( $8 \mathrm{mg} / \mathrm{kgBW}$ Doxorubicin) (400x) 
TABLE 1. Profile SIRT1 expression in each groups

\begin{tabular}{lccc}
\hline Rat groups & $\begin{array}{c}\text { SIRT1 expression } \\
(\text { Mean } \pm \text { SD) }\end{array}$ & $95 \%$ C.I. & $p$ \\
Normal & $0.12 \pm 0.035^{\mathrm{a}}$ & $0.0770-0.1630$ & $0.000^{*}$ \\
Corn oil & $0.13 \pm 0.025^{\mathrm{a}}$ & $0.1011-0.1629$ & \\
DMBA & $0.49 \mathrm{n} \pm 0.062^{\mathrm{b}}$ & $0.4087-0.5633$ & \\
EPI $1 \mathrm{mg} / \mathrm{kgBW}$ & $0.27 \pm 0.072^{\mathrm{ac}}$ & $0.1787-0.3573$ & \\
EPI $2 \mathrm{mg} / \mathrm{kgBW}$ & $0.19 \pm 0.038^{\mathrm{ad}}$ & $0.1390-0.2330$ & \\
EPI 4mg/kgBW & $0.14 \pm 0.025^{\mathrm{a}}$ & $0.1011-0.1629$ & \\
Doxorubicin $8 \mathrm{mg} / \mathrm{kgBW}$ & $0.14 \pm 0.030^{\mathrm{a}}$ & $0.1028-0.1772$ & \\
\hline
\end{tabular}

Distribution of data was tested by the Shapiro-Wilk: $\mathrm{p} \geq 0.05$. Data showed in mean \pm std. deviation. * One-Way Anova test significant: $\mathrm{p} \leq 0.05$. Bonferroni post hoc test with significant results are marked with a superscript notation

${ }^{a-b-c}$ Different superscripts value in the same column indicate significant differences $(p<0.05)$

${ }^{d}$ superscript indicates there is no significant difference compare ${ }^{c}$

\section{The effect of EPI on NF-кB expression among different rat groups.}

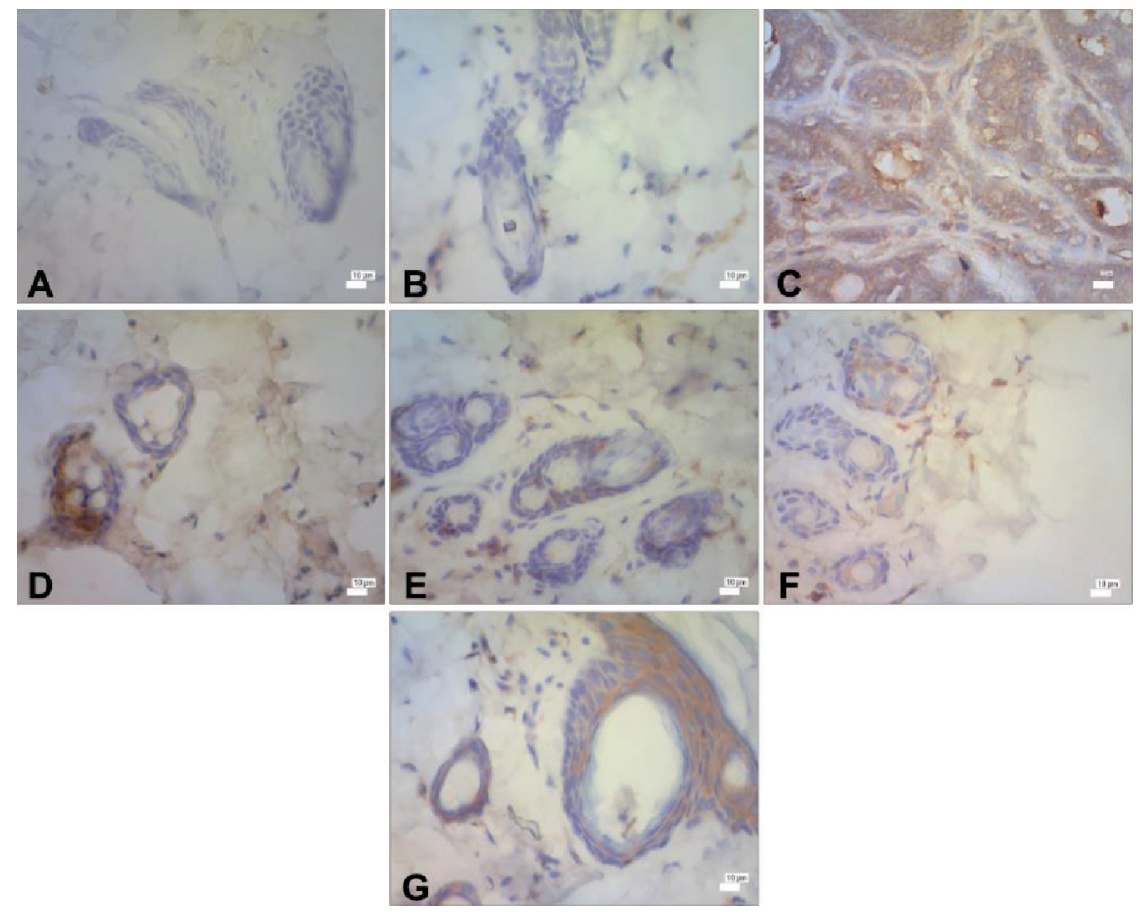

Figure 2. NF- $\quad \mathrm{B}$ expression in each groups. (A) Normal group; (B) Corn oil group; (C) DMBA group; (D) EPI I group (1 mg/kgBW EPI); (E) EPI II group (2 mg/kgBW EPI); (F) EPI III group (4 mg/kgBW $\mathrm{EPI})$; and (G) Doxorubicin group ( $8 \mathrm{mg} / \mathrm{kgBW}$ Doxorubicin) 
NF- $\kappa B$ p 65 was localized in the cytoplasm of breast cancer cells. NF- $\kappa B$ expression could not be found in normal group and corn oil group. The NF- $\mathrm{BB}$ p65 expression was clearly observed in DMBA group, EPI group, and Doxorubicin group. The strongest expression was observed in DMBA group. The lowest $\mathrm{NF}-\kappa \mathrm{B}$ expression was found in normal group $(0.17 \pm 0.044)$. Based on the measurement using Image $\mathbf{J}$ software, the highest expression level was found in DMBA group $(0.53 \pm 0.083)$. $\mathrm{NF}-\kappa \mathrm{B}$ expression level in EPI groups were generally lower than DMBA group, which were $0.31 \pm 0.038$ for EPI I, $0.20 \pm 0.025$ for EPI II, and $0.18 \pm 0.036$ for EPI III. The NF- $\mathrm{B}$ expression in doxorubicin group $(0.23 \pm 0.45)$ is closely similar to EPI II.

Table 2. Profile NF-кB expression in each groups.

\begin{tabular}{lccc}
\hline Rat groups & NF-kB expression (Mean \pm SD) & $95 \%$ C.I. & $p$ \\
\hline Normal & $0.17 \pm 0.044^{\mathrm{a}}$ & $0.1176-0.2264$ & $0.000^{*}$ \\
Corn Oil & $0.18 \pm 0.050^{\mathrm{a}}$ & $0.1185-0.2415$ & \\
DMBA & $0.53 \pm 0.083^{\mathrm{b}}$ & $0.4230-0.6290$ & \\
EPI $1 \mathrm{mg} / \mathrm{kgBW}$ & $0.31 \pm 0.038^{\mathrm{ac}}$ & $0.2670-0.3610$ & \\
EPI $2 \mathrm{mg} / \mathrm{kgBW}$ & $0.20 \pm 0.025^{\mathrm{a}}$ & $0.1748-0.2372$ & \\
EPI 4mg/kgBW & $0.18 \pm 0.036^{\mathrm{a}}$ & $0.1296-0.2184$ & \\
Doxorubicin 8mg/kgBW & $0.23 \pm 0.045^{\mathrm{a}}$ & $0.1655-0.2785$ & \\
\hline
\end{tabular}

Distribution of data was tested by the Shapiro-Wilk: $\mathrm{p} \geq 0.05$. Data showed in mean \pm std. deviation.

* One-Way Anova significant: $\mathrm{p} \leq 0.05$. Bonferroni post hoc test with significant results are marked with a superscript notation

${ }^{a-b-c}$ Different superscripts value in the same column indicate significant differences $(\mathrm{p}<0.05)$

${ }^{d}$ superscript indicates there is no significant difference compare ${ }^{c}$ superscript

One-Way ANOVA with post hoc Bonferroni test indicated that there is no significant difference between normal group and corn oil group $(\mathrm{p}=1.000$; data considered significantly different if $p<0.05$ ) (Table 2 ). It is assumed that corn oil as a DMBA solvent does not affect NF- $\kappa \mathrm{B}$ expression. One-Way ANOVA test showed that NF- $\kappa B$ expression in normal group $(\mathrm{p}=0.000)$ and EPI groups (EPI I, II EPI and EPI III) $(\mathrm{p}=0.000)$ were significantly lower than DMBA group NF- $\kappa \mathrm{B}$ expression among those three EPI groups showed that there was significant difference between EPI I and EPI II group ( $p=0.033)$; EPI II and EPI III $(p=0.002)$. However, there is no significant difference between EPI II an EPI III $(\mathrm{p}=1.000)$. Moreover, NF- $\kappa \mathrm{B}$ expression in doxorubicin group was significantly lower compared to DMBA group $(p=0.000)$ but does not have significant difference with EPI groups ( $p=0.123$ for EPI I; $p=1.000$ for EPI II and EPI III). 


\section{Correlation between SIRT1 and NF-кB expression in EPI-treated groups of DMBA- induced in Sprague Dawley rats}

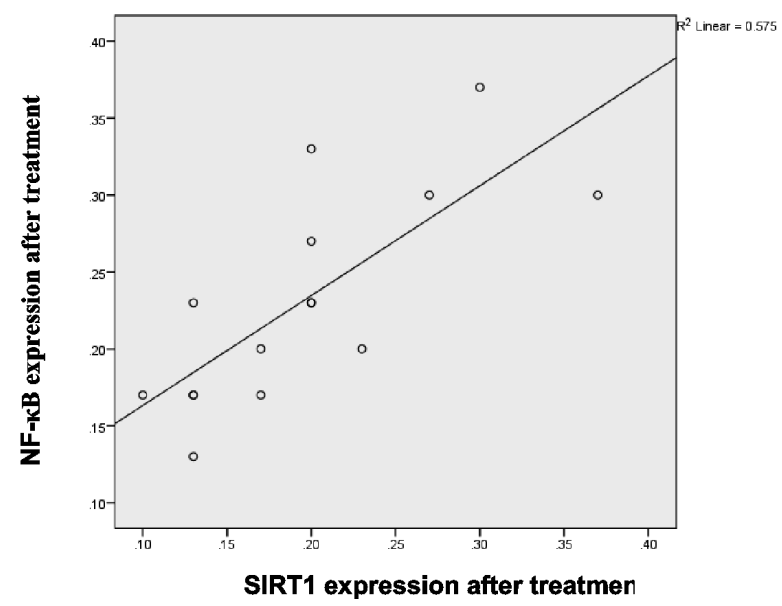

Figure 3. Scatter plot of SIRT1 and NF- $\mathrm{KB}$ expression after EPI treatment

In order to examine the correlation between SIRT1 and NF- $\kappa B$ expression in EPI-treated groups, linearity checking by using a scatter graph showed that. the data has an abnormal distribution, but there is linear relationship among the variables $(r 2=0.575)$ (FIGURE 3). Therefore, correlation between SIRT1 and NF- $\kappa \mathrm{B}$ expression in EPI-treated group was analyzed using Spearman correlation test.

Table 3. Spearman correlation test results between SIRT1 and NF- $\kappa$ B expression.

\begin{tabular}{lll}
\hline & \multicolumn{2}{l}{ NF- $\mathrm{B}$ expression } \\
SIRT1 expression & $\mathrm{r}=0.792$ \\
& $\mathrm{p}=0.001$ \\
$\mathrm{n}=$ & 15 \\
\hline
\end{tabular}

The Spearman correlation test found that there is a significant correlation between SIRT1 and NF- $\kappa$ B expression in EPI-treated groups $(p$-value $=0.001)$. The Spearman test also obtained $\mathrm{R}$-value $=0.792$ which indicated that there is a strong positive correlation between SIRT1 and NF- $\mathrm{kB}$ expression (Table $3)$.

\section{DISCUSSION}

Breast cancer is the most commonly diagnosed cancer in women around the world and statistically estimated at $29 \%(232,670)$ of all new cancer cases in women. ${ }^{14}$ Generally, breast cancer caused by a gene mutation, polymorphism, chemicals or carcinogenetic agent exposure, and several other factors. But, the biggest contribution to breast cancer pathogenesis is combination of exogenous factors such as diet, alcohol and pollution, as well as endogenous factors such as estrogens and progesterone exposures. ${ }^{3}$

Two proteins that expected to have a role in the pathogenesis of breast cancer are SIRT1 (Silent Information Regulator 1) and NF- $\mathrm{BB}$ (Nuclear Factor-kappaB), and they will be examined as endogenous factors. Exogenous factor used in this study is dimethylBenz 7.12 (a)anthracene (DMBA), a polycyclic aromatic hydrocarbons $(\mathrm{PaH})$ that often used to induce cancer in experimental animals. The interaction between DMBA and Aryl hydrocarbon receptor (AhR) on the surface of the cells will promote the tumorigenesis. This interaction will activate cytochrome p450 enzyme, in this case CYP1A1 and CYP1B1, which result in the oxidation of DMBA by CYP1A1 and CYP1B1 into 7.12-DMBA-3.4oxide. Furthermore, it will be converted into 7.12-DMBA-3.4-diol by epoxide hydrolase enzyme. Once DMBA converted into the diol form, it will be further oxidized by CYP1A1 and CYP1B1 into 7.12-DMBA-3.4-oxidediol-1.2-epoxide, which is a very potent carcinogenic. ${ }^{15}$ 


\section{The effect of EPI on SIRT1 expression among different rat groups.}

SIRT1 expression in normal $S D$ rats $(0.12 \pm 0.035)$ is significantly lower than the expression in DMBA group $(0.49 \pm 0.062)$ $(p=0.000)$. This is caused by activation of AhR by DMBA, which will interact with unliganded ER $\alpha$ and the entire AhR/ER $\alpha .{ }^{16}$ $\mathrm{ER} \alpha$ has direct interaction with SIRT1, and catalytically activate SIRT $1 .{ }^{17}$ This is consistent with tumorigenesis process, that proved with nodules formation in DMBAinduced Sprague Dawley. ${ }^{12,18}$ Similar results were obtained by Padauleng et al., ${ }^{18}$ which discovered that SIRT1 expression on DMBAinduced rat was higher than the un-induced ones. Furthermore, Padauleng et al. ${ }^{18}$ found that SIRT1 expression was observed in poor histological grade carcinoma $S D$ rats and there was a positive correlation between size of the nodules and PCNA proliferation marker with SIRT1 expression. This phenomenon proves the connection between SIRT1 with the development of breast cancer. ${ }^{18}$

SIRT1 mechanism in breast cancer development associated to the ability to deacetylate some molecules including tumor suppressor gene $\mathrm{p} 53,{ }^{5} \mathrm{p} 73,{ }^{6}$ and $\mathrm{HIC} 1 .{ }^{19}$ In addition to the capability in deacetylating tumor suppressor molecules, SIRT1 also able to regulate aromatase cytochrome p450 enzyme, including CYP19A1 group. CYP19A1 is an enzyme that contributes to increase estradiol concentrations. Estradiol is one of the main factors in the development of estrogen-dependent tumors. ${ }^{20}$

In this study, EPI treated groups have significantly lower SIRT1 expression compared to DMBA rat group ( $p<0.001)$. The EPI was administered prior to the DMBA inducement, which is indicated that EPI can prevent the increasing of SIRT1 expression. The results were similar to the one done by Kikuno et al., ${ }^{21}$ who found that decreasing SIRT1 expression in the cytoplasm of cell that treated by genistein. Kikuno et al., ${ }^{21}$ reported that an epigenetic pathway of genistein able to activate tumor suppressor gene by modulating either histone H3-Lysine 9 (H3K9) methylation or deacetylation at gene promoters. $^{21}$

Interestingly, Rasbach et al., ${ }^{22}$ reported that several isoflavone derivatives have contradictive effect on recombinant SIRT1 activity. Daidzein, formononetin, DCHC, and 7-C activate SIRT1 at low concentrations $(5-10 \mu \mathrm{M})$, and they further increase SIRT1 activity at $100 \mu \mathrm{M}$. In contrast, no SIRT1 activation was observed when treated by genistein, biochanin $\mathrm{A}, 7,4^{\prime}-D$, or $5,7,4$, $-T$. They explained that although the binding of the substituted isoflavone to SIRT1 has not been examined, but the presence of the 5-hydroxyl group in genistein and biochanin A can block the ability of these compounds to activate SIRT1, whereas the absence of the 5-hydroxyl group in daidzein and formononetin promotes SIRT1 deacetylation activity. Hereafter, substitution of a methoxy group for a hydroxyl group at the 7-position, as seen in 7, 4' $D$ and 5, 7, 5'-T, blocked SIRT1 activation. It suggests that a free hydroxyl group is necessary at the 7-position to promote SIRT1 deacetylase activity. ${ }^{22}$

\section{The effect of EPI on NF- $\mathrm{B}$ expression level among different rat groups.}

NF-kB expression level in normal $S D$ rats $(0.17 \pm 0.044)$ is significantly lower than DMBA group $(0.53 \pm 0.083)(p=0.000)$. In addition, DMBA-induced rats had positive breast carcinoma, characterized by the formation of nodules. ${ }^{12,18}$ It proves that NF- 
$\kappa \mathrm{B}$ expression is high in $S D$ rats with breast tumors. These results are consistent with study conducted by Rahman et al., ${ }^{23}$ who reported that presentation of $\mathrm{NF}-\kappa \mathrm{B}$ expression in DMBA-induced rats is higher than control group rat (corn oil-only). Furthermore, Rahman et al., ${ }^{23}$ found that increasing of $\mathrm{NF}-\kappa \mathrm{B}$ expression can be due to a mutation in the transcription factor $\mathrm{NF}-\kappa \mathrm{B}$ itself or in genes that regulate the activity of NF$\kappa \mathrm{B}$ such as I $\mathrm{B}$ gene. ${ }^{23}$ Currier et al.,${ }^{24}$ also reported that DMBA-induced tumor showed increased concentrations of transactivation complex of p50/p65, p50/c-Rel, p52/RelB. The transactivation complex acts as NF- $\mathrm{BB}$ transcription factor. Furthermore, increasing of transactivation complex will increase NF$\kappa \mathrm{B}$ expression. Once NF- $\kappa \mathrm{B}$ overexpression occurs, it will lead cell proliferation that cause tumorigenesis. ${ }^{24}$

$\mathrm{NF}-\kappa \mathrm{B}$ is able to regulate almost all aspects of tumor biology. NF- $\kappa \mathrm{B}$ can act as a promoter, as well as the capability to induce cell proliferation, promotion of metastasis and stimulate angiogenesis. In breast cancer, many studies have demonstrated the role of NF- $\kappa B$ in epithelial transition towards mesenchymal, which cause the tumor cell gained their motility and become invasive cancer cells. ${ }^{25}$ Therefore, inhibition of NF- $\kappa$ B can cause the death of tumor cells, and it prevents the tumor cells to proliferate and increases treatment responses. ${ }^{26}$

In this study, EPI administration was done prior to DMBA induction. EPI treated group have significantly lower NF- $\kappa B$ expression ( $p$ $<0.001)$ compared to the one in DMBA group. It indicated that the administration of EPI before DMBA inducement can prevent the increasing of NF- $\kappa B$ expression. Similar result has obtained by Davis et al. ${ }^{27}$ who found that genistein decreases NF- $\kappa$ B DNA binding and abrogates NF- $\kappa \mathrm{B}$ activation, which mediated by DNA-damaging agents, $\mathrm{H}_{2} \mathrm{O}_{2}$ and tumor necrosis factor- $\alpha$ (TNF- $\alpha$ ). ${ }^{27}$ The ability of isoflavone in inhibiting the activation of $\mathrm{NF}-\kappa \mathrm{B}$ is also observed in other cancer cell types. In T-cell lymphoma, genistein reduces the activity of NF- $\kappa B$ by cleavage $\mathrm{I} \kappa \mathrm{B} \alpha$ that mediated by caspase- $3 .^{28}$ In cystic human fibrosis bronchial glands case, genistein may regulate $\mathrm{I} \kappa \mathrm{B} \alpha$ that can inhibit the activation of NF- $\kappa \mathrm{B}$ and reduce the production of IL- $8 .{ }^{29}$

EPIhas similar structure with $17 \beta$-estradiol (estrogen, E2), which is suspected having a role in decreasing NF- $\kappa B$ expression. The similarity of EPI and $17 \beta$-estradiol makes the compound has the ability to bind to estrogen receptors ( $\alpha$ and $\beta$ ). ${ }^{30}$ Generally, it is assumed that ER $\alpha$ mediates estrogen induced proliferation and ER $\beta$ may inhibit cellular proliferation by antagonizing the actions of ER $\alpha .{ }^{31}$ Furthermore, genistein has a higher affinity to ER $\beta$ compared to ER $\alpha .{ }^{32}$ Xing et $a l .{ }^{33}$ found that ER $\beta$ inhibit the binding of p65 to NF- $\kappa B$ promoter, thus, it causes the reducing the NF- $\kappa B$ expression. Since the structure of EPI similar to $17 \beta$-estradiol, EPI can bind to ER $\beta$ and activates ER $\beta$ to inhibit p65 binding to the promoter. As a result, NF$\kappa B$ transcription also reduces. However, this assumption is still a hypothesis, because the activity of estrogen receptor (both ER $\alpha$ and $\mathrm{ER} \beta$ ) was not examined in this study.

\section{Correlation between SIRT1 and NF-кB expression in EPI-treated groups of DMBA- induced in Sprague Dawley rats}

In this study, EPI can prevent the increasing of SIRT1 and NF- $\kappa B$ expression in DMBAinduced $S D$ rat. The statistical analysis found that there is a positive correlation between SIRT1 and NF- $\kappa B$ expression in EPI-treated group. The ability of EPI to prevent the increasing of SIRT1 and NF- $\kappa B$ expression 
probably related to the ability of isoflavone derivate in regulating the expression of cytochrome p450 especially CYP1A1 and CYP1B1. The regulation of isoflavone derivate to the CYP1A1 and CYP1B1 was found by Shertzer et al., ${ }^{34}$ and Robert et al. ${ }^{35}$ Shertzer et al. ${ }^{34}$ They found that isoflavone derivate such as genistein, daidzein, and aglukon form can inhibit CYP1A1 and benzo[ $\alpha]$ pyrene $(\mathrm{BaP})$ to bind DNA strand. Robert et al., ${ }^{35}$ found that metabolites of daidzein and genistein can inhibit CYP1B1 which will further hamper cell proliferation. Moreover, biochanin A and formononetin have anti-carcinogenic effects due to the ability to compete with the substrate of CYP1B1. ${ }^{35}$ In consequence, the inhibition CYP1A1 and CYP1B1 enzyme will prevent the formation of carcinogenic agent of DMBA.

\section{CONCLUSION}

1,2-epoxy-3 [3- (3,4-dimetoksifenil) -4H-1-benzoiran-4-on) propane (EPI) at 1 $\mathrm{mg} / \mathrm{kgBW}, 2 \mathrm{mg} / \mathrm{kgBW}$ and $4 \mathrm{mg} / \mathrm{kgBW}$ can prevent the increasing of SIRT1 and NF$\kappa B$ expression in DMBA-induced Sprague Dawley rat model of breast cancer. There is a significant positive correlation between SIRT1 and NF- $\kappa B$ expression in EPI-treated group of DMBA-induced Sprague Dawley rat.

\section{ACKNOWLEDGEMENT}

The author would like to express gratitude to the Ministry of Research, Technology and Higher Education Republic of Indonesia (Kementerian Riset Teknologi dan Pendidikan Tinggi Republik Indonesia) for providing the fund, and to Department of Histology and Cell Biology for providing the material for conducting this research.

\section{REFERENCES}

1. McDonald M, Herts RP, Lowenthal SW. The Burden of Cancer USA. Pfizer Medical Division; 2008.

2. KEMENKES RI. InfoDATIN, STOP KANKER: Kementerian Kesehatan RI Pusat Data dan Informasi; 2015.

3. Abdulkareem I, Zurmi IB. Review of hormonal treatment of breast cancer. Niger J Clin Pract 2012; 15(1):9-14. http:dx.doi. org/10.4103/1119-3077.94088

4. Elangovan S, Ramachandran S, Venkatesan N, Ananth S, Gnana-Prakasam JP, Martin $\mathrm{PM}$, et al. SIRT1 is essential for oncogenic signalling by estrogen/estrogen alfa in breast cancer. Cancer Res 2011; 71(21):6654-64. http://dx.doi.org/10.1158/0008-5472.CAN11-1446

5. Vaziri H, Dessain S, Eaton EN, Imai SI, Frye RA, Pandita TK, et al. hSIR2(SIRT1) functions as an NAD-dependent p53 deacetylase. Cell 2001; 107(2):149-59. http:// dx.doi.org/10.1016/S0092-8674(01)00527-X

6. Dai JM, Wang ZY, Sun DC, Lin RX, Wang SQ. SIRT1 interacts with $\mathrm{p} 73$ and suppresses p73-dependent transcriptional activity. J Cell Physiol 2007; 210(1):161-6. http://dx.doi. org/10.1002/jcp.20831

7. Wong S, Weber JD. Deacetylation of the retinoblastoma tumour suppressor protein by SIRT1. Biochem J 2007; 407(3):451-60. http://dx.doi.org/10.1042/BJ20070151

8. Kuo SJ, Lin HY, Chien SY, Chen DR. SIRT1 suppresses breast cancer growth through downregulation of Bcl-2 protein. Oncol Rep 2013; 30(1):125-30. http://dx.doi.org/10.3892/or.2013.2470

9. Sas L, Lardon F, Vermeulen PB, Hauspy J, Van Dam P, Pauwels P, et al. The Interaction between ER and Nf-kappaB in Resistance to endocrine therapy. Breast Cancer Res 2012; 14(4):212. http://dx.doi.org/10.1186/bcr3196 
10. Biswas DK, Shi Q, Baily S, Stricland I, Ghosh S, Pardee AB, et al. Nf- $\kappa \mathrm{B}$ activation in human breast cancer specimens and its role in proliferation and apoptosis. Proc Natl Acad Sci USA 2004; 101(27):10137-42. http:// dx.doi.org/ 10.1073/pnas.0403621101

11. Hairil AA, Matsjeh S, Anwar C. Sintesis senyawa isoflavon dari minyak daun cengkeh dan uji aktivitas kanker secara in vitro. [Disertasi]. Yogyakarta: Universitas Gadjah Mada; 2010.

12. Herwiyanti S. Potensi Senyawa 1,2-Epoksi3[3-(3,4-dimetoksifenil)-4H-benzopiran4on]propana sebagai antikanker kajian in vitro akitvitas molekuler sel kanker payudara T47D dan MCF-7 serta aktivitas molekuler in vivo pada hewan model yang diinduksi 7,12-Dimetilbenz (a). [Disertasi]. Yogyakarta: Universitas Gadjah Mada; 2015.

13. Varghese F, Bukhari AB, Malhotra R, De A. IHC Profiler: an open source plugin for the quantitative evaluation and automated scoring of immunohistochemistry images of human tissue samples. PLos ONE 2014; 9(5):96801. http://dx.doi.org/10.1371/journal.pone. 0096801

14. Siegel R, Ma J, Zou Z, Jemal A. Cancer Statistic 2014. CA Cancer J Clin 2014; 64(1):9-29. http://dx.doi.org/10.3322/caac. 21208

15. Androutsopoulos VP, Tsatsakis AM, Spandidos DA. Cytochrome P450 CYP1A1: wider roles in cancer progression and prevention. BMC Cancer 2009; 9(187):1-17. http://dx.doi.org/10.1186/1471-2407-9-187

16. Ohtake F, Takeyama K, Matsumoto T, Kitagawa H, Yamamoto Y, Nohara K, et al. Modulation of oestrogen receptor signalling by association with the activated dioxin receptor. Nature 2003; 423(6939):545-50. http://dx.doi.org/10.1038/nature01606
17. Elangovan S, Ramachandran S, Venkatesan N, Ananth S, Ghana Prakasam JP, Martin PM, et al. SIRT1 is essential for oncogenic signaling by estrogen/estrogen receptor $\alpha$ in breast cancer. Cancer Res 2011; 71(21):665464. http://dx.doi.org/10.1158/0008-5472. CAN-11-1446

18. Padauleng N, Purnomosari D, Herwiyanti $\mathrm{S}$, Harjadi, Irianawati, Widyarini S. The relationship between sirtuin 1 (SIRT1) expression and tumor size, proliferating cell nuclear antigen (PCNA) expression and histological grading in rat breast carcinoma induced by dimethylbenz(alfa)anthracene (DMBA). [Tesis]. Yogyakarta: Universitas Gadjah Mada; 2013.

19. Chen WY, Wang DH, Yen RC, Luo J, Gu W, Baylin SB. Tumor suppressor HIC1 directly regulates SIRT1 to modulate p53-dependent DNA-damage responses. Cell 2005; 123(3):437-48. http://dx.doi.org/10.1016/j. cell.2005.08.011

20. Holloway RK, Barbieri A, Malyarchuk S, Saxena M, Kurepa AN, Mehl MC, et al. SIRT1 positively regulates breast cancer associated human aromatase (CYP19A1) expression. Mol Endocrinol 2013; 27(3):48090. http://dx.doi.org/10.1210/me.2012-1347

21. Kikuno N, Shiina H, Urakami S, Kawamoto $\mathrm{K}$, Hirata $\mathrm{H}$, Tanaka $\mathrm{Y}$, et al. Genistein mediated histone acetylation and demethylatio activates tumor suppressor genes in prostate cancer cells. Int J Cancer 2008; 123(3):55260. http://dx.doi.org/10.1002/ijc.23590.

22. Rasbach KA, Schnellmann RG. Isoflavones promote mitochondrial biogenesis. $\mathrm{J}$ Pharmacol Exp Ther 2008; 325(2):536-43. http://dx.doi.org/10.1124/jpet.107.134882

23. Rahman SA, Shaban N, Haggag A, Awad D, Bassiouny A, Talaat I. Inhibition of Nf$\kappa \mathrm{B}, \mathrm{Bcl}-2$ and $\mathrm{COX}-2$ gene expression by an extract of eruca sativa seeds during rat mammary gland carcinogenesis. Asian Pac 
J Cancer Prev 2015; 16(18):8411-18. http:// dx.doi.org/10.7314/APJCP.2015.16.18.8411

24. Currier N, Solomon SE, Demicco EG, Chang $\mathrm{DL}$, Farago $\mathrm{M}$, Ying $\mathrm{H}$, et al. Oncogenic signaling pathways activated in DMBAinduced mouse mammary tumors. Toxicol Pathol 2005; 33(6):726-37. http://dx.doi. org/10.1080/01926230500352226

25. Shostak K, Chariot A. Nf-kB, stem cell and breast cancer: the links get stronger. Breast Cancer Res 2011; 13(4):214. http://dx.doi. org/10.1186/bcr2886

26. Escarcega RO, Fuentes-Alexandro S, GarciaCarrasco M, Gatica A, Zamora A. The transcription factor nuclear factor-kappa $\mathrm{B}$ and cancer. Clin Oncol (R Coll Radiol) 2007; 19(2):154-61. http://dx.doi.org/10.1016/j. clon.2006.11.013

27. Davis JN, Kucuk O, Sarkar FH. Genistein inhibits NF-kappa B activation in prostate cancer cells. Nutr Cancer 1999; 35(2):167-74. http://dx.doi.org/ 10.1207/ S15327914NC352_11

28. Baxa DM, Yoshimura FK. Genistein reduces NF-kappa $\mathrm{B}$ in $\mathrm{T}$ lymphoma cells via a caspase-mediated cleavage of I-kappa-Balpha. Biochem Pharmacol 2003; 66(6):1009$18 . \quad \mathrm{http} / / \mathrm{dx}$.doi.org/10.1016/S00062952(03)00415-5

29. Tabary O, Escotte S, Coutil JP, Hubert $\mathrm{D}$, Dusser D, Puchelle E, et al. Genistein inhibits constitutive and inducible NFkappaB activation and decreases IL-8 production bt human cystic fibrosis bronchial gland cells. Am J Pathol 1999; 155(2):473-81. http://
dx.doi.org/10.1016/S0002-9440(10)65143-7

30. Messina MJ, Wood CE. Soy isoflavones, estroge therapy, and breast cancer risk: analysis and commentary. Nutr J 2008; 7:17. http://dx.doi.org/10.1186/1475-2891-7-17

31. Speirs V, Walkers RA. New perspectives into the biological and clinical relevance of oestrogen receptors in the human breast. J Pathol 2007; 211(5):499-506. http://dx.doi. org/ 10.1002/path.2130

32. Kuiper GG, Lemmen JG, Carlsson B, Corton JC, Safe SH, van der Saag PT, et al. Interaction of estrogen chemicals and phytoestogens with estrogen receptor beta. Endocrinology 2013; 139(10):4252-63. http://dx.doi.org/10.1210/ endo.139.10.6216

33. Xing D, Oparil S, Yu H, Gong K, Feng W, Black $\mathrm{J}$, et al. Estrogen modulates NFkB signalling by enhancing $\mathrm{IkBa}$ levels and blocking p65 binding at the promoters of iflammatory genes via estrogen receptorBeta. PLoS ONE 2012; 7(6):36890. http:// dx.doi.org/10.1371/journal.pone.0036890

34. Shertzer HG, Puga A, Chang C, Smith P, Nebert DW, Setchell KD, et al. Inhibition of CYP1A1 enzyme activity in mouse hepatoma cell culture by soybean isoflavones. Chem Biol Interact 1999; 123(1):31-49. http:// dx.doi.org/10.1016/S0009-2797(99)00121-0

35. Robert DW, Doerge DR, Churchwell MI, da Costa GG, Marques MM, Tolleson WH. Inhibiton of extrahepatic human cytochromes P450 1A1 and 1B1 by metabolism of isoflavones found in trifolium pratense (Red Clover). J Agric Food Chem 2004; 52(21):6623-32. http:dx.doi.org/10.1021/ jf049418x 